\title{
UPAYA MENINGKATKAN KUALITAS PELAYANAN PERPUSTAKAAN DI POLITEKNIK NEGERI TANAH LAUT
}

\author{
Hamidah \\ Politeknik Negeri Tanah Laut \\ J1. A. Yani Km. 6 Ds. Panggung Kec. Pelaihari Kab. Tanah Laut, Kalimantan Selatan \\ E-mail: hamidahatqia@gmail.com
}

\begin{abstract}
Abstrak
Tujuan dari penelitian ini adalah untuk mengetahui bagaimana kualitas layanan perpustakaan di Politeknik Negeri Tanah Laut dan untuk menentukan upaya yang tepat dalam meningkatkan kualitas pelayanan perpustakaan di Politeknik Negeri Tanah Laut. Metode yang digunakan dalam penelitian ini adalah LibQual+ TM yaitu suatu metode untuk mengukur kualitas layanan perpustakaan berdasarkan tiga dimensi yang dijadikan indikator pengukuran yaitu Affect of service (Sikap dan kemampuan petugas dalam melayani pemustaka), Information Control (Ketersediaan koleksi dan kemudahan akses informasi) dan Library as Place (Perpustakaan sebagai sebuah tempat). Teknik pengumpulan data menggunakan kuesioner.

Hasil penelitian ini menunjukkan bahwa secara umum kualitas layanan di Perpustakaan Politeknik Negeri Tanah Laut masih dalam batas zona toleransi atau dinyatakan baik Hal ini dibuktikan bahwa nilai ratarata harapan minimum yaitu 4,53 dan nilai rata-rata persepsi adalah 5,33, sedangkan nilai rata-rata harapan yang diinginkan (desired) yaitu 6,18. Dengan demikian dapat diketahui bahwa nilai rata-rata persepsi lebih tinggi dari harapan minimum, sehingga diperoleh nilai kesenjangan AG (Adequacy Gap) positif yaitu 0,79 dan nilai SG (Superiority Gap) sebesar - 0,85.
\end{abstract}

Kata kunci : Upaya, Kualitas Pelayanan Perpustakaan

\section{PENDAHULUAN}

Perpustakaan merupakan salah satu pusat sumber belajar yang dapat digunakan oleh pemakai (mahasiswa, dosen, dan masyarakat) dalam upaya mengembangkan kemampuan dan kecakapannya. Perpustakaan merupakan jantung dari suatu lembaga pendidikan, dimana pendidik dan peserta didik dapat menggali pengetahuan dan wawasan secara mendalam di perpustakaan.Tanpa adanya perpustakaan, maka pendidikan tidak dapat berjalan sebagaimana mestinya. Seiring perkembangan ilmu pengetahuan dan teknologi, perpustakaan kini bukan lagi menjadi satu-satunya pusat sumber belajar, akan tetapi perpustakaan merupakan salah satu pusat sumber belajar. Hal ini terjadi karena sumber belajar dapat dicari melalui berbagai sumber, seperti media cetak, media massa, internet, dan sebagainya.

Pelayanan perpustakaan akan terselenggara dengan baik apabila ditunjang dengan peralatan dan perlengkapan yang sesuai sudah. Sesuai atau belum dengan harapan penggunanya. Perubahan terhadap kualitas pelayanan dapat terjadi, karena dipengaruhi oleh gejala sosial maupun perkembangan teknologi informasi. Kualitas pelayanan yang baik tentunya didasarkan pada kepuasan yang dirasakan oleh pengguna perpustakaan dan bukan dari penyedia pelayanan.

\section{RUMUSAN MASALAH}

Penelitian ini dilakukan untuk mengetahui Bagaimana kualitas pelayanan perpustakaan di Politeknik Negeri Tanah Laut saat ini dan bagaimana upaya meningkatkan kualitas pelayanan pada perpustakaan Politeknik Negeri Tanah laut.

\section{TINJAUAN PUSTAKA}

\section{Kualitas Pelayanan Perpustakaan}

Menurut Sutarno (2006:90)

Layanan perpustakaan merupakan salah 
satu kegiatan utama disetiap perpustakaan dimana layanan tersebut merupakan kegiatan yang langsung berhubungan dengan masyarakat dan sekaligus merupakan barometer keberhasilan perpustakaan. Pelayanan perpustakaan merupakan kegiatan yang memberikan layanan yang baik sebagaimana dikehendaki oleh pemakai dalam pemberiaan informasi.

Parasuraman, Berry dan Zeithaml (1985: 41) mendefinisikan persepsi terhadap kualitas layanan sebagai a global budgment,or attitude, relating to the superiority of the service (Penilaian umum/banyak orang,bukan individu) sedangkan kualitas layanan (service quality) adalah the gap betweencustomers's expectation for excellent service and their perceptions of service delivered.

Kualitas layanan dianggap baik, bila skor persepsi lebih tinggi dari skor harapan, dan sebaliknya, kualitas layanan dianggap belum baik bila skor persepsi lebih rendah dari skor harapan (Secara umum pengertian kepuasan pelanggan atau ketidak puasan pelanggan merupakan perbedaan antara harapan (expectation) dan kinerja yang dirasakan (perceived performance).

\section{Dimensi Pengukuran Kualitas Layanan}

Menurut cook dalam khaerudin (2015) LibQual+ ${ }^{\mathrm{TM}}$ adalah suite layanan perpustakaan yang digunakan untuk mengumpulkan memahami, dan bertindak atas pendapat pemustaka mengenai kualitas layanan. Program ini berbasis survei web dan digabungkan dengan pelatihan perpustakaan yang membantu menilai dan meningkatkan layanan perpustakaan, memungkinkan penilaian sistematis dalam mengukur kualitas layanan perpustakaan.

Prinsip LibQual $+^{\mathrm{TM}}$ adalah "only customer judge quality, all other judgmentsare essentially irrelevant" (hanya pengguna yang berhak menilai kualitas layanan, seluruh penilaian lain sebenarnya tidaklah relevan). Metode ini digunakan untuk mengukur kualitas layanan perpustakaan berdasarkan persepsi dan harapan pengguna.

Terdapat tiga dimensi LibQual+ ${ }^{\mathrm{TM}}$ yang dijadikan variabel pengukuran, yaitu: 1. Affect of service, yaitu kemampuan, sikap dan mentalitas petugas perpustakaan dalam melayani pengguna.

2. Information Control, yaitu menyangkut tentang ketersediaan koleksi yang memadai, kekuatan koleksi yang dimiliki, cakupan isi (scope of content), kemudahan akses untuk menemukan koleksi, kemudahan navigasi (ease ofnavigation), aktualitas (timeliness), waktu yang dibutuhkan dalam mendapatkan informasi, ketiadaan hambatan dalam mengakses informasi pada saat dibutuhkan, peralatan (equipment), kenyamanan (convenience) danself reliance (kepercayaan diri).

3. Library as place, yaitu perpustakaan sebagai sebuah tempat, ini diambil dari konsep tangibles dalam ServQual, yaitu kemampuan menampilkan sesuatu secara nyata berupa fasilitas fisik (physical fasilities), dan bagaimana perpustakaan dalam memanfaatkan ruang (utilitarian space).

Penelitian terdahulu yang menjadi rujukan dalam penelitian ini adalah sebagai berikut:

1. Tika Ayuningtyas (2015) dalam penelitiannya yang berjudul" Kualitas Layanan di Perpustakaan Umum Kota Madiun (Studi Diskriptif Tentang Kualitas Layanan Dengan menggunakan LibQual di Perpustakaan Umum Kota Madiun). Teknik analisis 
data yang digunakan dalam penelitian ini adalah menggunakan metode kuantitatif deskriptif dengan teknik pengambilan sampel secara Purposive sampling sebanyak 100 responden. Hasil penelitian menjelaskan bahwa:

a. Kualitas Pelayanan yang diberikan perpustakaan Umum kota madiun berdasarkan dimensi pengaruh pelayanan (Affect of service) di nilai masih rendah. Dimensi ini menilai mengenai sikap pustakawan meliputi empati, daya tanggap, jaminan dan kehandalan. Hal itu diartikan bahwa kualitas pelayanan yang diberikan pustakawan belum memenuhi aspek layanan yang baik.

b. Kualitas layanan yang diberikan perpustakaan umum kota Madiun berdasarkan dimensi penguasaan informasi (information control) dinilai sedang dimana layanan yang diberikan segi koleksi akses informasi, dan fasilitas fisik telah memenuhi aspek layanan yang baik.

c. Kualitas layanan yang diberikan perpustakaan umum kota Madiun berdasarkan dimensi lokasi perpustakaan (library as place) di nilai sedang. Dimensi ini menggunakan indicator penilaian tentang lokasi perpustakaan, jam buka yang ideal, keberadaan perpustakaan, makna perpustakaan, tingkat kenyamanan, keamanan, dan perpustakaan dapat memberikan inspirasi dan ide-ide. Dari hasil yang didapatkan, kualitas layanan yang diberikan perpustakaan umum kota Madiun belum memenuhi aspek layanan yang baik.

2. M. Khaerudin (2015) dalam penelitiannya yang berjudul" Kualitas Layanan Perpustakaan Esa Unggul
Dari Sudut Pandang Pemustaka (Mahasiswa S1, S2, dan Dosen) Menggunakan Metode LibQual. Teknik analisis yang digunakan dalam penelitian ini menggunakan statistik deskriptif dengan sampel penelitian 100 responden. Hasil penelitian menjelaskan bahwa:

a. Kualitas layanan Perpustakaan Universitas Esa Unggul dari sudut pandang mahasiswa $\mathrm{S} 1$ terdapat 2 dimensi yang belum memenuhi harapan minimum, yakni dimensi affect of service dan information control.

b. Kualitas layanan Perpustakaan Universitas Esa Unggul dari sudut pandang mahasiswa S2 terdapat 1 dimensi yang belum memenuhi harapan minimum, yakni dimensi affect of service.

c. Kualitas layanan Perpustakaan Universitas Esa Unggul dari sudut pandang dosen terdapat 2 dimensi yang belum memenuhi harapan minimum, yakni dimensi information control dan library as place.

Berdasarkan landasan teori dan rumusan masalah sebelumnya, maka kerangka berpikir penelitian ini adalah sebagai berikut :

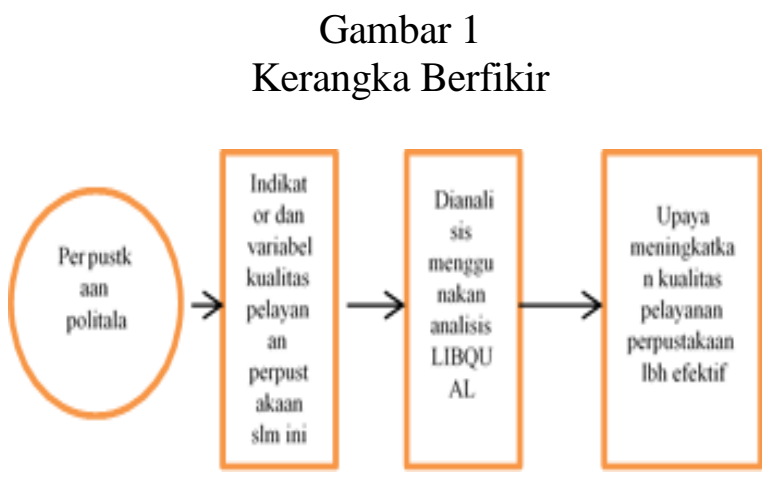

METODE PENELITIAN

Penelitian ini menggunakan pendekatan kuantitatif, karena data yang 
digunakan berupa angka angka dan pengolahannya menggunakan data statistik. Menurut Sugiyono (2012: 7) metode penelitian kuantitatif dapat diartikan sebagai metode penelitian yang berlandaskan pada filsafat positivisme, digunakan untuk meneliti pada populasi atau sampel tertentu.

\section{Populasi dan Sampel Penelitian}

Populasi dalam penelitian ini adalah seluruh sivitas akademika Politeknik Negeri Tanah Laut. Dalam penelitian ini jumlah populasi diketahui secara pasti, maka untuk menentukan besar sampel yang diambil dapat dihitung dengan menggunakan rumus Slovin (Husien Umar, 2005: 78) yaitu sebagai berikut:$$
=\frac{\mathrm{N}}{1+\left(\mathrm{Ne}^{2}\right)}
$$

Dimana :

$\mathrm{n}=$ Ukuran sampel

$\mathrm{N}=$ Ukuran Populasi

$\mathrm{E}=$ kelonggaran ketidaktelitian karena pengambilan sampel yang masih dapat ditolerir $5 \%$.

$\mathrm{n}=\frac{694}{1+\left(694 \times 0,05^{2}\right)}=3$ orang

\section{Definisi Operasional Variabel}

Menurut Sugiyono (2012: 60), variabel adalah segala sesuatu yang berbentuk apa saja yang ditetapkan oleh peneliti untuk dipelajari sehingga diperoleh informasi tentang hal tersebut, kemudian ditarik kesimpulannya. Variabel yang digunakan dalam penelitian ini ada dua yaitu variabel terikat dan variabel bebas. Variabel terikat dalam penelitian ini adalah responden yang menilai kualitas pelayanan perpustakaan, sedangkan variabel bebasnya adalah kreteria yang dinilai yaitu affect of service, comonication control, dan library as place.
Penelitian ini menggunakan metode LibQual+TM yang merupakan metode untuk mengukur kualitas layanan perpustakaan berdasar persepsi pengguna dengan menggunakan tiga dimensi kualitas layanan yaitu affect of service, information control dan library as place. Metode LibQual+ ${ }^{\mathrm{TM}}$ ini pada dasarnya adalah bertujuan untuk mengukur kualitas layanan berdasarkan dimensi tersebut yang merupakan adaptasi dari item-item dalam servqual yang telah dimodifikasi dan disesuaikan dengan lingkungan perpustakaan (Cook, 2013).

Tiga dimensi tersebut dapat dilihat dari tabel indikator berikut:

1. Affect of Service

a. Kemampuan dan kepercayaan diri petugas Perpustakaan dalam memberikan layanan.

b. Keinginan untuk menolong

c. Sikap petugas dalam menghadapi kesulitan pengguna.

d. Kecepatan petugas dalam memberikan layanan.

e. Pengetahuan petugas perpustakaan.

f. Cara berpakaian dan respon petugas terhadap pengguna.

\section{Information Contro.}

a. Ketepatan koleksi untuk kebutuhan pengguna.

b. Ketersediaan jurnal tercetak

c. Akses terhadap informasi secara mudah dan independen bagi pengguna.

d. Akses sumber informasi dalam format digital yang dapat diakses dimana saja.

\section{Library as Place}

a. Ketenangan suasana perpustakaan.

b. Suasana nyaman perpustakaan untuk diskusi dan belajar.

c. Ruang perpustakaan yang dapat memberikan inspirasi. 
d. Fasilitas ruang perpustakaan.

Pengukuran kualitas pelayanan dalam LibQual+ TM dilakukan berdasarkan harapan dan persepsi pengguna. Terdapat dua jenis harapan yang digunakan dalam pengukuran kualitas layanan, yaitu harapan minimum (minimum expectation) dan harapan yang diinginkan (desired). Harapan minimum merupakan harapan pengguna terhadap layanan perpustakaan yang dapat diterima (acceptable), sedangkan harapan sesungguhnya (desired) merupakan harapan pengguna terhadap layanan perpustakaan yang secara pribadi mereka inginkan. Persepsi (perceived adalah tingkat layanan perpustakaan yang dirasakan oleh pengguna.

\section{Teknik Analisis Data}

Analisis kualitas layanan perpustakaan dilakukan dengan menggunakan data yang diperoleh dari penyebaran kuesioner kepada responden. Analisis data ini menggunakan statistik deskriptif dimana metode analisis yang digunakan berkaitan dengan pengumpulan dan penyajian suatu gugus data sehingga memberikan informasi yang jelas. Teknik analisis data statistik deskriptif ini digunakan untuk menganalisis harapan dan persepsi responden terhadap seluruh variabel penelitian. Prosedur analisis data yang dilakukan sebagai berikut:

1. Menghitung total skor harapan minimum, total skor harapan yang diinginkan (desired) dan total skor persepsi (perceived) untuk setiap butir pernyataan.

2. Menghitung skor rata-rata harapan minimum, harapan yang dinginkan (desired) dan persepsi (perceived).

3. Membandingkan skor rata-rata harapan minimum, harapan yang diinginkan (desired) dan persepsi (perceived), sehingga akan diperoleh skor kesenjangan (gap score) untuk mengetahui kualitas layanan.

Terdapat tiga istilah dalam perhitungan ini yaitu:

1. AG yaitu Adequacy Gap adalah nilai selisih yang diperoleh dari rumus: $P$ (Perceived) - M (Minimum).

2. SG yaitu Superority Gap adalah nilai selisih yang diperoleh darirumus: $\mathrm{P}$ (Perceived) - D (Desired).

3. Zone of tolerance

Rumus:

$\mathrm{AG}=\mathrm{P}-\mathrm{M}$ (Perceived - Minimum)

$\mathrm{SG}=\mathrm{P}-\mathrm{D}$ (Perceived-Desired).

Keterangan:

1. Apabila skor SG (Superiority Gap) menunjukkan nilai positif, hal ini menunjukkan nilai negatif, hal ini berada pada 'zone of tolerance', dimana kualitas layanan berada diantara tingkat minimum yang dapat diterima dan tingkat harapan yang diinginkan (desired).

2. Apabila skor AG (Adequacy Gap) menunjukkan nilai positif, hal ini menunjukkan bahwa layanan yang diberikan telah memenuhi harapan pemustaka, dapat diartikan pula bahwa pemustaka cukup puas terhadap layanan yang diterimanya.

3. Apabila skor AG (Adequacy Gap) menunjukkan nilai negatif, hal ini menunjukkan bahwa pelayanan yang diberikan belum memenuhi harapan pemustaka, dapat diartikan pula bahwa pemustaka tidak puas terhadap layanan yang diterimanya.

\section{HASIL DAN PEMBAHASAN}

\section{Uji Validitas dan Realibilitas}

Menurut Sugiono (2012) untuk menguji validitas dilakukan dengan cara 
mengkorelasikan antara skor butir pertanyaan dengan skor totalnya. Rumus yang digunakan untuk menguji validitas instrument ini adalah Product Moment dari Karl Pearson, sebagai berikut:

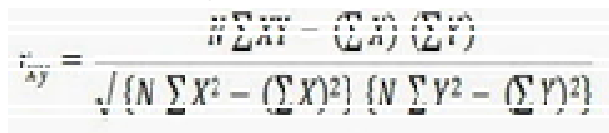

Kemudian hasil dari rxy dikonsultasikan dengan harga kritis product moment ( $\mathrm{r}$ tabel), apabila hasil yang diperoleh $\mathrm{r}$ hitung $>\mathrm{r}$ tabel, maka instrumen tersebut valid.

Dalam praktiknya untuk menguji validitas kuesioner ini penulis menggunakan bantuan software Microsoft Office Excel dan Statistical Product and Service Solution (SPSS). Sehingga didapat hasil sebagai berikut: Valid : $\mathrm{r}$ hitung > r tabel $r$ tabel: $\mathrm{N}(378)-2=376$ dilihat dari $r$ untuk df 376 adalah 0,10.

Untuk validitas pertanyaan, nilai korelasi (pearson correlation) terkecil adalah 0,14 untuk dimensi affect of service dan library as place, dan 0,16 untuk dimensi informatioan control. Nilai yang lebih besar dari batas $0,10(\mathrm{n}=378$, $\mathrm{dk}=376)$ menunjukkan bahwa item tiap pertanyaan dalam kuesioner dinyatakan valid. Untuk reliabilitas dapat terlihat dari nilai croncbach's alfa sebesar 0.655 , nilai tersebut di atas nilai batas reliabel yaitu 0,5 berarti adanya konsistensi yang tinggi (reliable). Berdasarkan hasil ini maka seluruh butir pertanyaan tersebut dapat dinyatakan valid dan reliable.

\section{Kualitas Pelayanan Perpustakaan di Politeknik Negeri Tanah La}

Dari hasil perhitungan secara umum menunjukkan bahwa nilai rata-rata harapan minimum yaitu 4,53 dan nilai ratarata persepsi adalah 5,33 sedangkan nilai rata-rata harapan yang diinginkan (desired) yaitu 6,18. Dengan demikian dapat diketahui bahwa nilai rata-rata persepsi lebih tinggi dari harapan minimum, sehingga diperoleh nilai kesenjangan AG (Adequacy Gap) positif yaitu 0,8 dan nilai SG (Superiority Gap) negatif yaitu sebesar $-0,85$.

Hal tersebut menunjukkan bahwa pemustaka menilai kualitas layanan yang diterimanya telah memenuhi harapan minimum yang diinginkan sehingga pemustaka dapat dinyatakan cukup puas dengan layanan yang diberikan. Dengan demikian, dapat dikatakan bahwa secara umum, kualitas layanan perpustakaan di Politeknik Negeri Tanah Laut sudah memuaskan responden. Hasil analisis data dapat dilihat pada tabel berikut ini:

Tabel 1

Hasil Analisis Secara Umum

\begin{tabular}{|r|c|c|c|c|c|}
\hline $\begin{array}{c}24 \text { Butii } \\
\text { Pernyataan }\end{array}$ & $\begin{array}{c}\text { Harapan } \\
\text { Minimum }\end{array}$ & Desired & $\underline{\text { Persepsi }}$ & $(\mathrm{AG})$ & $(\mathrm{SG})$ \\
\hline Rata-rata & 4,53 & 6,18 & 5,33 & 0,79 & $-0,85$ \\
\hline
\end{tabular}

Angka 0,79 tersebut menunjukkan bahwa Adequacy Gap adalah positif dan berada pada wilayah'zone of tolerance', yang berarti kualitas layanan masih dalam batas toleransi atau dinyatakan baik.

Dari hasil perhitungan berdasarkan dimensi pelayanan menunjukkan bahwa pada dimensi Affect of service, nilai ratarata pada harapan yang diinginkan (desired) lebih tinggi dari harapan minimum.

Nilai harapan yang diinginkan adalah 5,92 dan nilai rata rata harapan minimum yaitu 4,62, sedangkan nilai ratarata persepsi adalah 5,45. Data tersebut menunjukkan bahwa nilai rata-rata persepsi lebih tinggi dari harapan minimum, sehingga memperoleh nilai 
kesenjangan (Adequacy Gap) positif yaitu 0,83 dengan nilai Superior Gap -0,47. Hal serupa juga terjadi pada dimensi information control dan library as place yang menunjukkan nilai rata-rata persepsi lebih tinggi dari harapan minimum. Hasil analisis data dapat dilihat pada table berikut ini:

Tabel 2

Hasil Analisis Data Berdasarkan Dimensi Kualitas Layanan

\begin{tabular}{|c|c|c|c|c|c|}
\hline $\begin{array}{c}\text { Dimensi Kualitas } \\
\text { Layanan }\end{array}$ & Minimum & Desired & Persepsi & (AG) & (SG) \\
\hline Affect of service & 4,62 & 5,92 & 5,45 & 0,83 & $-0,47$ \\
\hline information control & 4,48 & 6.16 & 4,82 & 0,34 & $-1,33$ \\
\hline library as place & 4,50 & 6,46 & 5,72 & 1,22 & $-0,73$ \\
\hline
\end{tabular}

Kemudian analisis data

berdasarkan butir pernyataan ditemukan lima pernyataan yang nilai kesenjangan AG (Adequacy Gap) mendapat skor lebih rendah atau belum memenuhi harapan responden yaitu:

1. Pustakawan memiliki pengetahuan yang baik dan memberikan pelayanan dengan cepat dan tepat

2. Automasi perpustakaan membuat layanan sirkulasi lebih cepat

3. Layanan katalok online/OPAC membuat penelusuran informasi di perpustakaan menjadi muda

4. Pengguna mudah dalam mengakses informasi secara mandiri

5. Adanya layanan internet di perpustakaan membantu dalam mengakses informasi.

\section{Upaya Meningkatkan Kualitas Pelayanan Perpustakaan di Politeknik Negeri Tanah Laut}

Berdasarkan analisis kualitas pelayanan untuk meningkatkan kualitas pelayanan perpustakaan di Politeknik Negeri Tanah Laut maka upaya yang perlu dilakukan dan menjadi perhatianan manajemen perpustakaan adalah:

1. Berdasarkan data jawaban responden terhadap pertanyaan waktu buka perpustakaan maka secara umum pengguna perpustakaan di Politeknik Negeri Tanah Laut merasa bahwa perpustakaan sebaiknya memberi layanan 6 hari dalam seminggu dan sebagian lagi menginginkan perpustakaan buka setiap hari. Ini menunjukkan pengguna perpustakaan di Politeknik Negeri Tanah Laut meganggap keberadaan perpustakaan penting untuk memenuhi kebutuhannya.

2. Pengembangan pengetahuan petugas perpustakaan dan penambahan jumlah petugas di perpustakaan perlu menjadi perhatian manajemen perpustakaan Politeknik Negeri Tanah Laut untuk mewujudkan pelayanan yang cepat dan tepat di perpustakaan.

Layanan internet di perpustakaan Politeknik Negeri Tanah Laut sangat diperlukan oleh pemustaka, untuk peningkatan fasilitas layanan internet maka diperlukan penambahan jumlah unit komputer yang dapat digunakan pemustaka dalam mengakses informasi. Sehingga harapan sesungguhnya pengguna perpustakaan dalam hal information control dapat terpenuhi.

\section{KESIMPULAN}

Dari hasil penelitian ini maka dapat ditarik kesimpulan bahwa:

1. Secara umum kualitas layanan perpustakaan di nilai baik oleh penggunanya.

2. Kualitas layanan perpustakaan yang belum memenuhi harapan minimum menurut pengguna perpustakaan adalah dimensi layanan affect of service dan information control. 
Berdasarkan analisis kualitas pelayanan maka untuk meningkatkan kualitas pelayanan perpustakaan di Politeknik Negeri Tanah Laut maka manajemen perpustakaan perlu memperhatikan peningkatan wawasan SDM dan layanan internet untuk mempermudah pengguna perpustakaan dalam mengakses informasi.

\section{DAFTAR PUSTAKA}

Ayuningtyas Tika, 2013, Kualitas Layanan Perpustakaan Umum Kota Madiun (Studi Diskriptif Tentang Kualitas Layanan Dengan Menggunakan LIBQUAL di Perpustakaan Umum Kota Madiun), Universitas Airlangga, Surabaya.

Cook, Collen and Fred, M. H. 2001, User
Perseption of Library Servis Quality: A LibQual Qualitatif Study, Library Trends, Spring.

Husin, Umar, 2005, Metode Penelitian, Salemba Empat, Jakarta.

Khaerudin, M, 2015, Kualitas Layanan Perpustakaan Esa Unggul Dari Sudut Pemustaka Dari Sudut Pemustaka (Mahasiswa S1, S2, Dan Dosen) Menggunakan Metode Libqual+TM, Universitas Indonesia, Jakarta.

Parasuraman, A., VA, Zeithhaml, dan L.L. Berry. A 1985, A Conceptual Model of Service Quality and its Implication for Future Research, Journal of Marketing,Vol. 49, Fall, pp. 41-50. 